\title{
COMPARATIVE STUDY OF CATCH IN OPEN WATER FISH HABITATS BOTH INSIDE AND OUTSIDE THE EMBANKMENT OF MEGHNA DHONAGODA IRRIGATION PROJECT
}

\author{
MD. MOTAHER HOSSAIN ${ }^{1 *}$, MOHAMMAD SHAFI $^{2}$, MD. KAWSER AHMED $^{3}$, \\ MOHAMMAD ABU JAFOR BAPARY ${ }^{1}$ AND MD. LOKMAN HOSSAIN ${ }^{4}$ \\ ${ }^{I}$ Department of Fisheries Technology and Quality Control, Faculty of Fisheries, Sylhet \\ Agricultural University, Sylhet-3100, Bangladesh \\ ${ }^{2}$ Department of Fisheries, Faculty of Biological Sciences, University of Dhaka, Dhaka-1000, \\ Bangladesh \\ ${ }^{3}$ Department of Marine science, University of Dhaka, Dhaka-1000, Bangladesh \\ ${ }^{4}$ Department of Zoology, Dhaka College, Dhaka-1000, Bangladesh
}

\begin{abstract}
A comparative study of production /catch in open water fish habitats was conducted both inside and outside the embankment of Meghna Dhonagoda Irrigation Project (MDIP). Very low production was observed in the khal/canal $(24.32 \mathrm{~kg} / \mathrm{ha}$ and $26.45 \mathrm{~kg} / \mathrm{ha})$, inundated paddy field/ floodplain $(1.99 \mathrm{~kg} / \mathrm{ha}$ and $2.24 \mathrm{~kg} / \mathrm{ha})$ in inside the embankment in 2003-2004 and 2004-2005, where the production/Catch per unit area was higher in khal $(531.56 \mathrm{~kg} / \mathrm{ha}$ and $528.77 \mathrm{~kg} / \mathrm{ha})$, floodplain $(38.18 \mathrm{~kg} / \mathrm{ha}$ and $33.84 \mathrm{~kg} / \mathrm{ha})$ in outside during the same years. Beside these, the production/catch was recorded in irrigation canal $(13.90 \mathrm{~kg} / \mathrm{ha}$ and $21.94 \mathrm{~kg} / \mathrm{ha})$ in inside the embankment of both the years. On the other hand, the catch was recorded in Meghna river (137.87 kg /ha and $96.27 \mathrm{~kg} / \mathrm{ha})$ and in Dhonagoda river $(124 \mathrm{~kg} / \mathrm{ha}$ and $85.92 \mathrm{~kg} / \mathrm{ha})$ in outside the embankment of both the years respectively. The production was little bit higher in inside open water habitats in 2004-2005, escaped fishes from the ponds were also caught in the inside open water habitats in 2004-2005 due to the over flooding of ponds caused by excess rainfall in September 2004. In both the years, the highest production of inside habitats was in khal, followed by irrigation canal and inundated paddy field/ floodplain. In case of outside habitats, the highest production was in khal, followed by Meghna river, Dhonagodariver and floodplain during both the years of study. Monthly estimated catch regarding the production of the equal sample area of the same habitats between the two zones are statistically significant $(\mathrm{p}<0.05)$ in both 2003-2004 and 2004-2005.
\end{abstract}

Key words: Catch, Open water, Fish habitats, Embankment, MDIP

\section{Introduction}

The fisheries resource of Bangladesh is one of the most important one in Asia covering about one percent of the total world fish catch (FAO 1997 and Hossain 1998). In the early sixties, open water fisheries contributed about 70-75\% of the total fish production, which in recent years has dropped to 50\% (DOF 1999). According to BFRSS (20032004), the inland open water contributed $34.83 \%$ of the total fish production which dropped to $27.79 \%$ in 2014-15. According to DOF (2016), total fish production was

* Corresponding author: E-mail: motaher03@yahoo.com 
36.84 lakh $\mathrm{mt}, 3.65 \%$ to GDP and Bangladesh became $4^{\text {th }}$ in inland open water fish production in 2014-2015. So, fisheries sector plays an important role regarding employment generation, animal protein supply, foreign currency earning and poverty alleviation. About 12 million people are directly or indirectly involved in this sector. Labour employment in this sector has been increasing approximately by $3.5 \%$ annually. In Bangladesh, fish provides up to $63 \%$ of animal proteins consumed (BBS 2001and DOF 2005).

Over 12.4 million people are estimated to be engaged in one way another inland fisheries production, this population consists of 1.4 million full-time professional fishermen and over 11 million part-time or occasional fishermen and a small percentage of fish farmers. Fisheries sector provides $7 \%$ of our total national employment. Large numbers of people depend directly or indirectly on the fisheries sector for their livelihood.

Of all the sources, the inland open water is the most important source of fish production in Bangladesh. Major production comes from the naturally grown and bred fish from the open water system. The open water and the floodplain are very rich in natural fish food and as a result the open water fishes do not require supplementary feeding. The open water is also a very important source of employment to rural fishermen.

In Bangladesh, the fish catch from the inland open water capture fishery is decreasing while the demand for fish is increasing along with the increase in population. The fish yield from the rivers and estuaries except Sundarban area has decreased from 207,766 mt in $1983-84$ to $173,410 \mathrm{mt}$ in $1989-90,138,746 \mathrm{mt}$ in $1992-93,137,848 \mathrm{mt}$ in $2002-2003$ and 137,337 mt in 2003-2004 respectively (BFRSS 1983-84 to 2003-2004).

The details of the impact of flood control projects on fisheries are as follows: loss of catch through loss of fish habitat, reduction in catch per unit area (CPUA) reduced fish density / abundance, increase fishing effort, reduced biodiversity, reduction in the number of migratory fish and number of migrations, disruption of fishermen community structure, increased fish capture at regulators, reduced opportunity for mitigation measures and reduced potential for stock enhancement (FAP 17 1995). In surveys of fishermen, up to $75 \%$ of the reduction has been blamed on the FCDI project (Nishat and Bhuiyan 1995). Ali and Zaman (1989) have depicted the trends of effects of flood control and drainage (FCD) projects on floodplain loss and floodplain fish production in Bangladesh.

The inland open water like floodplains and beels were once exceptionally rich in wild fish, which contributed significantly to national nutritional requirements. But in recent years, fish production from these sources has declined alarmingly for many reasons such as construction of embankments, regulators and sluice gates, water pollution, over fishing etc. (BCAS 1991 and DOF 1995). The FAP-12 (1992a) observed that FCD and FCDI projects had major negative impacts on capture fisheries, resulting from substantial reductions in the areas of inundated floodplains and permanent beels and by the blockage 
of fish migration routes. Many fishermen lost their livelihood or been diverted to river fisheries, leading to over fishing in these areas, adversely affecting the fish migration potential.

The Meghna Dhonagoda Irrigation Project (MDIP) is a medium scale, flood control, drainage and irrigation (FCD/I) project. The project area is composed of 15 unions of Matlab North upazila under Chandpur district. The area is an island circumscribed by the Meghna and Dhonagoda rivers. It was constructed between 1982 and 1987. It provides flood control and drainage to 17584 ha area of land and irrigation to 13602 ha area. The whole embankment is $60 \mathrm{~km}$. The whole project area is flat and used to remain submerged by flood water from April-May to November. Before construction the embankment there were large numbers of khals serving as drainage channels as well as channels for transport. A large segment of the human population (fishermen, landless and other disadvantaged people) was dependent on this rich capture fishery production for their livelihood and employment throughout the duration of monsoon inundation. But after construction of embankment, the loss of capture fishery has devastated the life of many people who were dependent on this capture fishery for their livelihood.

Halls et al. (2000) stated that fish production in floodplains river systems is largely dependent upon the timing, extent and duration of flood pulse, all of which can be severely modified by hydraulic engineering. CPUA was found to be $38-51 \%$ lower inside the Pabna Irrigation and Rural Development Project (PIRDP) flood control, drainage and irrigation scheme during both sampling years, although fishing effort could not account for these differences. The inland open water like floodplains and beels were once exceptionally rich in wild fish, which contributed significantly to national nutritional requirements. But in recent years, fish production from these sources has declined alarmingly for many reasons such as construction of embankments, regulators and sluice gates, water pollution, over fishing etc. (BCAS 1991 and DOF 1995) and the objectives of this study were

- To know the inland open water habitat-wise catch/production both inside and outside the embankment of MDIP

- To compare the catch between the habitats of inside and outside the embankment.

\section{Materials and Methods}

Catch Assessment Survey : Fish (habitat-wise) catch assessment survey was performed to find out extent of the existing capture fishery, gear-wise catch per unit effort, catch per unit area of different open water fish habitats in both inside and outside of the two selected embankments/ regulators. The survey was conducted for two years (2003-2004, 2004-2005). 
Catch assessment survey of each habitat (Khal, inundated paddy field, irrigation canal, floodplain, river etc.) of open water fisheries both inside and outside of MDIP was performed. Habitats of inside of the embankment were inundated paddy field, khal, irrigation canal and the habitats of the outside of the embankment were khal, floodplain and rivers. At least $10 \%$ area from each habitat of both inside and outside of the embankment was selected for catch assessment survey. The survey was carried out fortnightly in each habitat and monthly gear-wise catch data was estimated for each habitat. Two types of questionnaires were used for the survey. Firstly, the total fishing unit of each gear was counted in the selected fishing habitat as per proforma of the questionnaire. Then another questionnaire was used for the fishermen in each selected fishing habitat. Gear-wise data were collected from the each sample unit. The number of sample unit for each type of gear was followed according to DOF Catch Assessment Manual (BFRSS 1990). One sample unit consisted of single gear, one boat (when present) and single or more than one fisherman. The number of sample units depended on the number of operated units and these were as follows:

\begin{tabular}{cc}
\hline Number of operated unit & Number of sample unit \\
\hline 1 & 1 \\
$2-4$ & 2 \\
$5-9$ & 3 \\
10 and above & 5 \\
\hline
\end{tabular}

Gear-wise and group-wise monthly estimated catch was determined by using the Calculation Sheet of Monthly Estimated Catch.

The estimated daily catch was found by multiplying the average daily catch and the average operated unit. Thus the estimated monthly catch was found by multiplying the estimated daily catch and the number of fishing days.

Statistical analysis: Statistical analysis was done to find the significant difference between the monthly estimated catch of the same habitat of equal sample area of inside and outside the embankment. Mainly t-test (independent and paired t-test) is done for significant test.

\section{Results and Discussion}

Habitat-wise inland open water fish production / catch: In inside the embankment of MDIP, it was observed that the production / catch in irrigation canal was $13.90 \mathrm{~kg} / \mathrm{ha}$, khal (24.32 kg/ha), inundated paddy field / flood plain (1.99 kg/ha) in 2003-2004. But in outside the embankment the production / catch in khal was $531.56 \mathrm{~kg} / \mathrm{ha}$, floodplain $(38.18 \mathrm{~kg} / \mathrm{ha})$, Megna river $(137.87 \mathrm{~kg} / \mathrm{ha})$ and Dhonagoda river $(124 \mathrm{~kg} / \mathrm{ha})$ in the same study period (Fig.1 and Table 1). 


\section{3-2004 Inside 2003-2004 Outside}

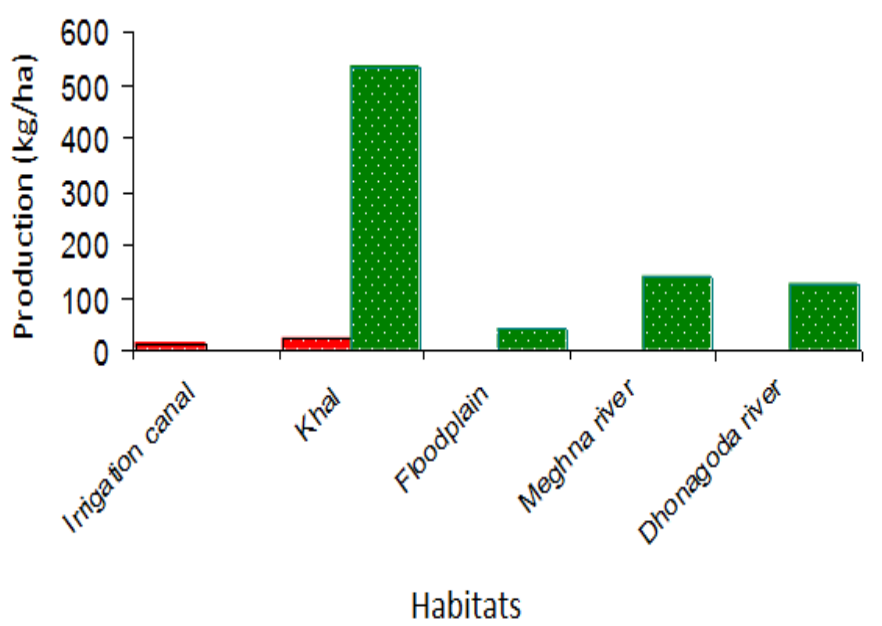

Fig.1. Habitat-wise catch / production both inside and outside of MDIP in 2003-2004.

From Fig. 2 and Table 2, it is apparent that the production/catch of inland open water such as, in irrigation canal was $21.94 \mathrm{~kg} / \mathrm{ha}$, khal $(26.45 \mathrm{~kg} / \mathrm{ha})$, inundated paddy field (2.24 kg / ha) in 2004-2005.On the other hand, the production/catch of the outside habitats such as in khal was $528.77 \mathrm{~kg} / \mathrm{ha}$, floodplain (33.84 kg / ha), Meghna river (96.27 kg / ha), Dhonagoda river $(85.92 \mathrm{~kg} / \mathrm{ha})$.

Table 1. Habitat- wise production of fish (catch of open water fisheries) in inside and outside of MDIP during April, 2003-March, 2004.

\begin{tabular}{|c|c|c|c|c|c|}
\hline $\begin{array}{l}\text { SL } \\
\text { No. }\end{array}$ & $\begin{array}{c}\text { Name of the fish } \\
\text { habitat }\end{array}$ & $\begin{array}{l}\text { Position of the } \\
\text { fish habitat }\end{array}$ & $\begin{array}{c}\text { Area of } \\
\text { sample size } \\
\text { (ha) }\end{array}$ & $\begin{array}{c}\text { Total } \\
\text { production or } \\
\text { catch }(\mathrm{kg})\end{array}$ & $\begin{array}{l}\text { Production } \\
\text { (kg/ha) }\end{array}$ \\
\hline 1 & Irrigation canal & $\begin{array}{l}\text { Inside the } \\
\text { embankment }\end{array}$ & 5.97 & 83 & 13.90 \\
\hline 2 & Khal & $\begin{array}{l}\text { Inside the } \\
\text { embankment }\end{array}$ & 20.23 & 492 & 24.32 \\
\hline 3 & $\begin{array}{l}\text { Inundated paddy } \\
\text { field (Floodplain) }\end{array}$ & $\begin{array}{l}\text { Inside the } \\
\text { embankment }\end{array}$ & 180.16 & 359 & 1.99 \\
\hline 4 & Khal & $\begin{array}{l}\text { Outside the } \\
\text { embankment }\end{array}$ & 3.58 & 1903 & 531.56 \\
\hline 5 & Floodplain & $\begin{array}{l}\text { Outside the } \\
\text { embankment }\end{array}$ & 48.58 & 1855 & 38.18 \\
\hline 6 & Meghna river & $\begin{array}{l}\text { Outside the } \\
\text { embankment }\end{array}$ & 322.29 & 44435 & 137.87 \\
\hline 7 & Dhonagoda river & $\begin{array}{l}\text { Outside the } \\
\text { embankment }\end{array}$ & 228.29 & 28490 & 124.80 \\
\hline
\end{tabular}


In both the years, the highest production of inside habitats was in khal, followed by irrigation canal and inundated paddy field / floodplain. In case of outside habitats, the highest production was in khal, followed by Meghnariver, Dhonagoda river and floodplain during both years of study.

\section{4-2005 Inside 国 2004-2005 Outside}

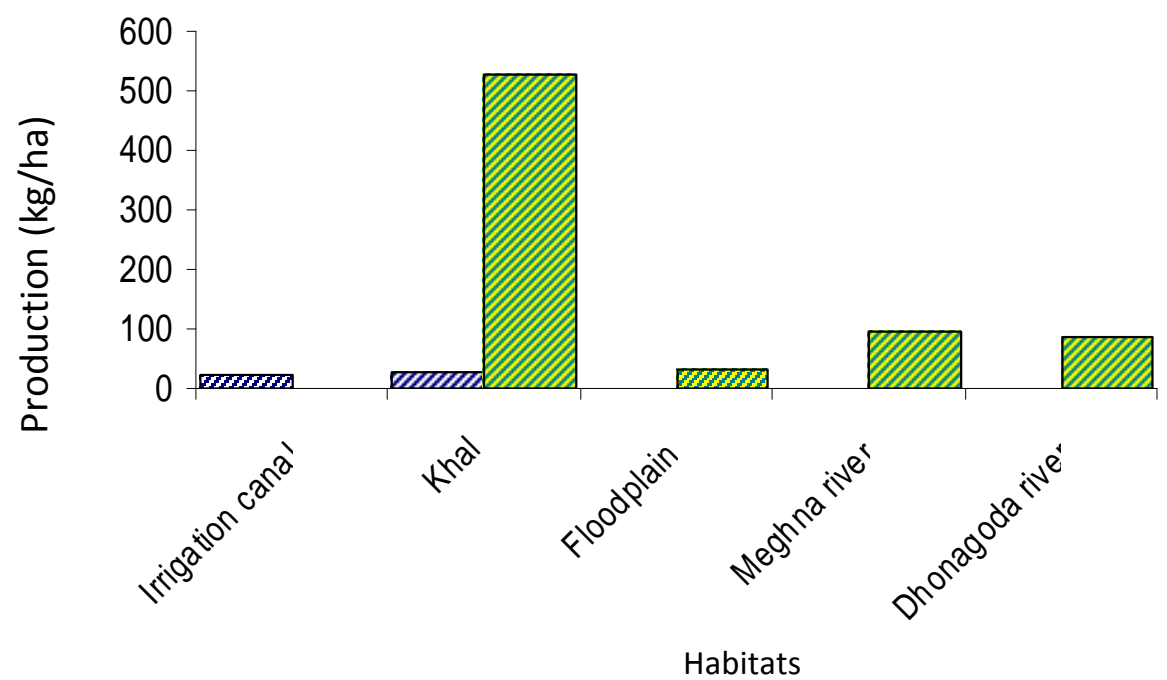

Fig. 2. Habitat-wise catch / production both inside and outside of MDIP in 2004-2005.

Table 2. Habitat- wise production of fish (catch of open water fisheries) in inside and outside of MDIP during April, 2004-March, 2005.

\begin{tabular}{|c|c|c|c|c|c|}
\hline SL No. & $\begin{array}{c}\text { Name of the fish } \\
\text { habitat }\end{array}$ & $\begin{array}{l}\text { Position of the } \\
\text { fish habitat }\end{array}$ & $\begin{array}{c}\text { Area of } \\
\text { sample size } \\
\text { (ha) } \\
\end{array}$ & $\begin{array}{c}\text { Total } \\
\text { production or } \\
\text { catch }(\mathrm{kg}) \\
\end{array}$ & $\begin{array}{l}\text { Production } \\
\text { (kg/ha) }\end{array}$ \\
\hline 1 & Irrigation canal & $\begin{array}{l}\text { Inside the } \\
\text { embankment }\end{array}$ & 5.97 & 131 & 21.94 \\
\hline 2 & Khal & $\begin{array}{l}\text { Inside the } \\
\text { embankment }\end{array}$ & 20.23 & 535 & 26.45 \\
\hline 3 & $\begin{array}{l}\text { Inundated paddy } \\
\text { field(Floodplain) }\end{array}$ & $\begin{array}{l}\text { Inside the } \\
\text { embankment }\end{array}$ & 180.16 & 404 & 2.24 \\
\hline 4 & Khal & $\begin{array}{l}\text { Outside the } \\
\text { embankment }\end{array}$ & 3.58 & 1893 & 528.77 \\
\hline 5 & Floodplain & $\begin{array}{l}\text { Outside the } \\
\text { embankment }\end{array}$ & 48.58 & 1644 & 33.84 \\
\hline 6 & Meghna river & $\begin{array}{l}\text { Outside the } \\
\text { embankment }\end{array}$ & 322.29 & 31026 & 96.27 \\
\hline 7 & Dhonagoda river & $\begin{array}{l}\text { Outside the } \\
\text { embankment }\end{array}$ & 228.29 & 19614 & 85.92 \\
\hline
\end{tabular}




\section{Monthly estimated catch}

(a) Khal (inside) : Fig. 3 shows that a total of $492 \mathrm{~kg}$ of fish was caught in different months throughout the year (2003-2004) by different types of gears. In September, the highest quantity of $159 \mathrm{~kg}$ of fish was caught, followed by August, $105 \mathrm{~kg}$ of fish, October, $97 \mathrm{~kg}$ of fish, July, $69 \mathrm{~kg}$ of fish and June, $53 \mathrm{~kg}$ of fish respectively (Fig. 3).

In 2004-2005, Fig. 3 shows that a total of $535 \mathrm{~kg}$ of fish was caught in different months of the year by different types of gear. In September, the highest quantity of $328 \mathrm{~kg}$ of fish was caught, followed by October, $77 \mathrm{~kg}$ of fish, August, $72 \mathrm{~kg}$ of fish, July, $36 \mathrm{~kg}$ of fish and June $17 \mathrm{~kg}$ of fish respectively (Fig.3). It was also observed that the total catch was $492 \mathrm{~kg}$ in the inside khal in 2003-2004, whereas, the total catch was $535 \mathrm{~kg}$ in 2004-2005 in the same area, which was slightly higher than the previous year, In both years, the highest catch was in the month of September and in this month, the catch was more than double in 2004-2005 than 2003-2004 (Fig.3).

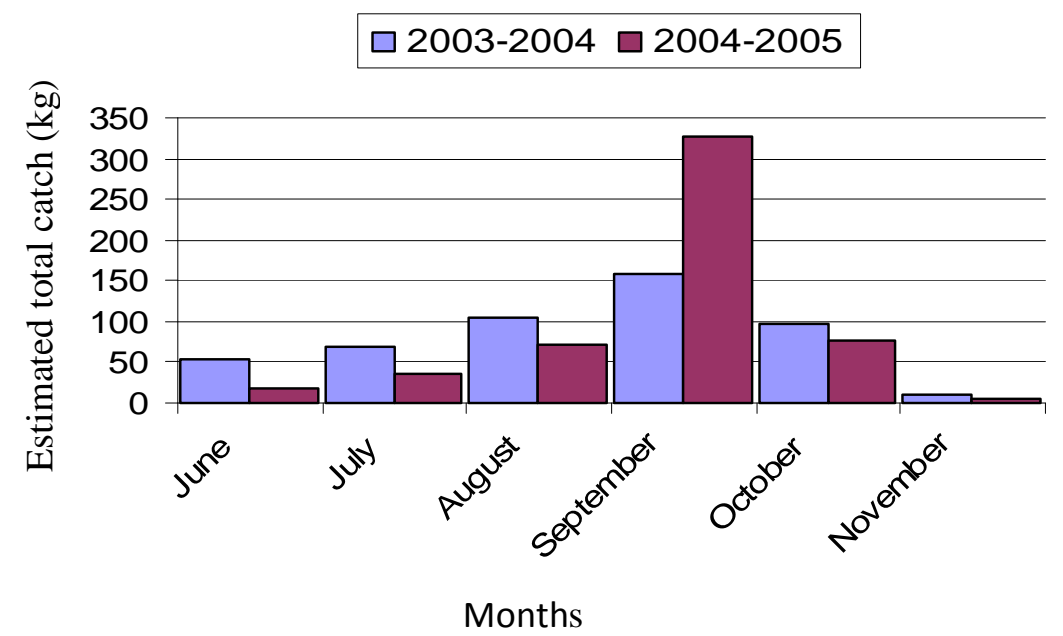

Fig. 3.Monthly estimated catch of khal (inside) of MDIP in 2003-2004 and 2004-2005.

(b) Irrigation canal (inside) : Fig. 4 shows that a total of $83 \mathrm{~kg}$ of fish was caught in different months during the period of 2003-2004 by different types of gears. In July, the highest quantity of $24 \mathrm{~kg}$ of fish was caught, followed by September, $20 \mathrm{~kg}$ of fish, August, $14 \mathrm{~kg}$ of fish, June, $13 \mathrm{~kg}$ of fish respectively (Fig. 4).

In 2004-2005, Fig. 4 shows that a total of $131 \mathrm{~kg}$ of fish was caught in different months of the year by different types of gears. In September, the highest quantity of $85 \mathrm{~kg}$ of fish was caught, followed by July, $13 \mathrm{~kg}$ of fish, June, $12 \mathrm{~kg}$ of fish, August, $10 \mathrm{~kg}$ of fish and $4 \mathrm{~kg}$ of fish respectively (Fig.4). 
It was also noted that the total catch was $83 \mathrm{~kg}$ in irrigation canal in 2003-2004, while, the total catch was $131 \mathrm{~kg}$ in 2004-2005 in the same area which was comparatively higher than 2003-2004. During 2004-2005, the maximum catch was in the month of September but more or less equal and highest catch was in the months of July and September in 2003-2004 (Fig.4). The highest catch in the month of September in 20042005 was four times higher than the highest catch in the month of July or September in 2003-2004.

\section{$\square$ 2003-2004 $\square$ 2004-2005}

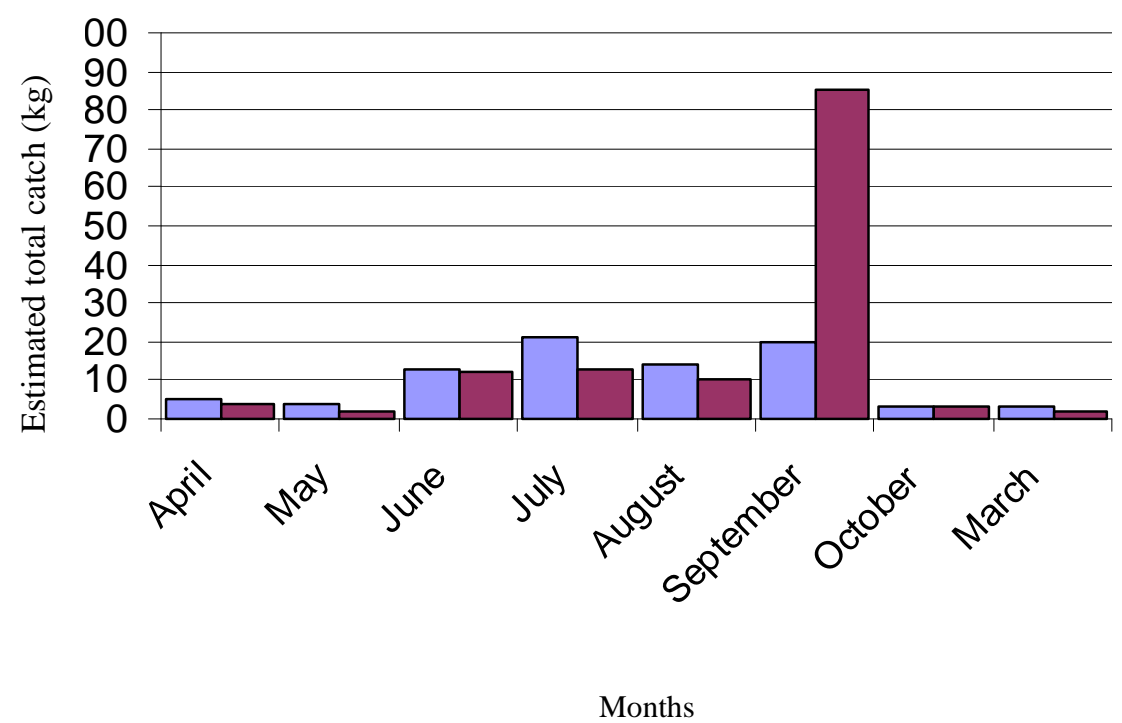

Fig. 4. Monthly estimated catch of Irrigation canal (inside) of MDIP in 2003-2004 and 2004-2005.

(c) Khal (outside) : Fig. 5 illustrates that a total of $1903 \mathrm{~kg}$ of fish was caught in different months during the period of 2003-2004 by various sorts of gears. In the month of October, the highest quantity of $859 \mathrm{~kg}$ of fish was caught, followed by September, 454 kg, August, $269 \mathrm{~kg}$, July, $143 \mathrm{~kg}$, November, $81 \mathrm{~kg}$, December, $47 \mathrm{~kg}$ correspondingly (Fig. 5). For the duration of 2004-2005, Fig. 5 shows that a total of $1893 \mathrm{~kg}$ of fish was caught in different months of the year by various kinds of gears. In October, the highest quantity $(697 \mathrm{~kg}$ ) of fish was caught, the second highest was $678 \mathrm{~kg}$, after that $238 \mathrm{~kg}$ in August, $122 \mathrm{~kg}$ in July and $63 \mathrm{~kg}$ in November respectively (Fig. 5 ).

It was also found that the total catch was $1903 \mathrm{~kg}$ in outside khal in 2003-2004 which remained nearly unchanged in 2004-2005 with $1893 \mathrm{~kg}$. 


\section{3-2004 2004-2005}

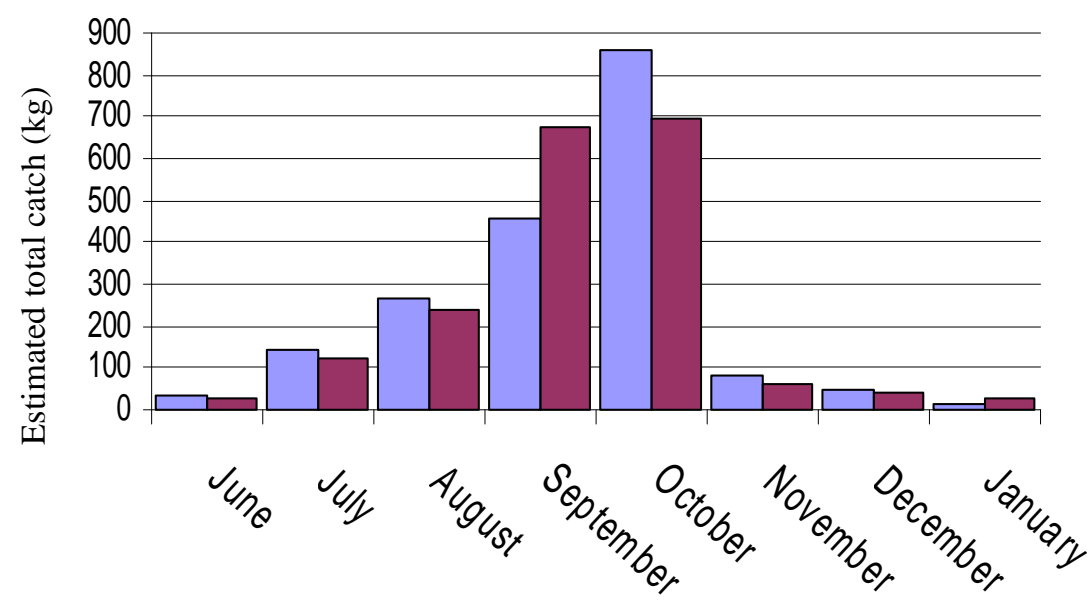

Months

Fig. 5. Monthly estimated catch of khal (outside) of MDIP in 2003-2004 and 2004-2005.

(d) Inundated paddy field / floodplain (inside) : Fig.6 shows that a total of $359 \mathrm{~kg}$ of fish was caught in different months throughout the year (2003-2004) by different sorts of gears. The highest quantity of $183 \mathrm{~kg}$ of fish was caught in August, after that $169 \mathrm{~kg}$ in July and $7 \mathrm{~kg}$ in September (Fig. 6).

It was also observed that total catch was $359 \mathrm{~kg}$ in the inundated paddy field / floodplain inside during 2003-2004, where, the total catch was $404 \mathrm{~kg}$ in 2004-2005 in the same area, which was higher than the foregoing year.

In 2003-2004, the highest catch was in the month of August, where it was in the month of September in 2004-2005. But the lowest catch (7 kg) was in September during 20032004. 


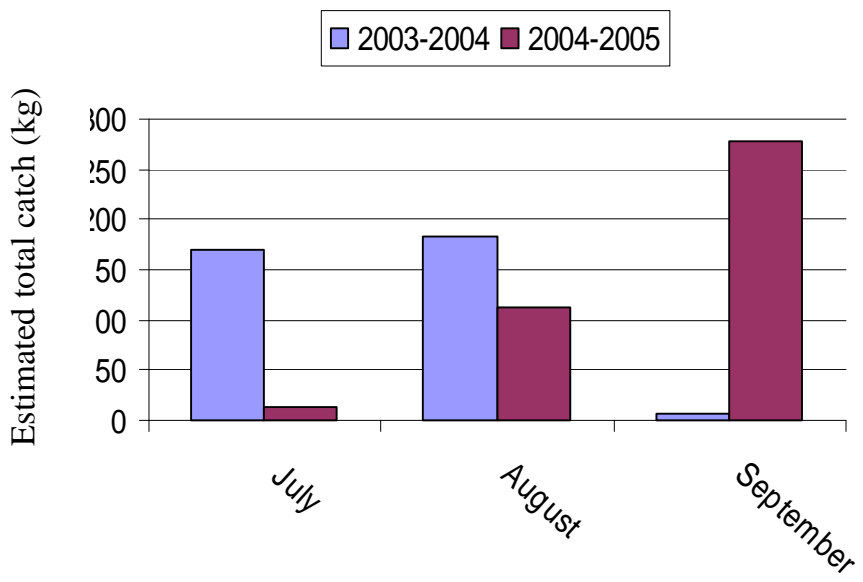

Months

Fig. 6. Monthly estimated catch of inundated paddy field (inside) of MDIP in 2003-2004 and 2004-2005.

(f) Floodplain (outside) : Fig. 7 shows that a total of $1855 \mathrm{~kg}$ of fish was caught in different months during 2003-2004 by different kinds of gears. In the month of August, the highest quantity of $735 \mathrm{~kg}$ of fish was caught, followed by September, $577 \mathrm{~kg}$, July, $488 \mathrm{~kg}$ and October, $55 \mathrm{~kg}$ respectively (Fig. 7). In 2004-2005, Fig. 7 shows that a total of $1644 \mathrm{~kg}$ of fish was caught in different months by various types of gears. In September, the highest quantity of $744 \mathrm{~kg}$ of fish was caught, followed by $506 \mathrm{~kg}$ in August, $349 \mathrm{~kg}$ in July and $45 \mathrm{~kg}$ in October correspondingly (Fig. 7.). It was also found that the total catch $1855 \mathrm{~kg}$ in outside floodplain in 2003-2004 was higher than the total catch $(1644 \mathrm{~kg})$ in $2004-2005$ in the same area.

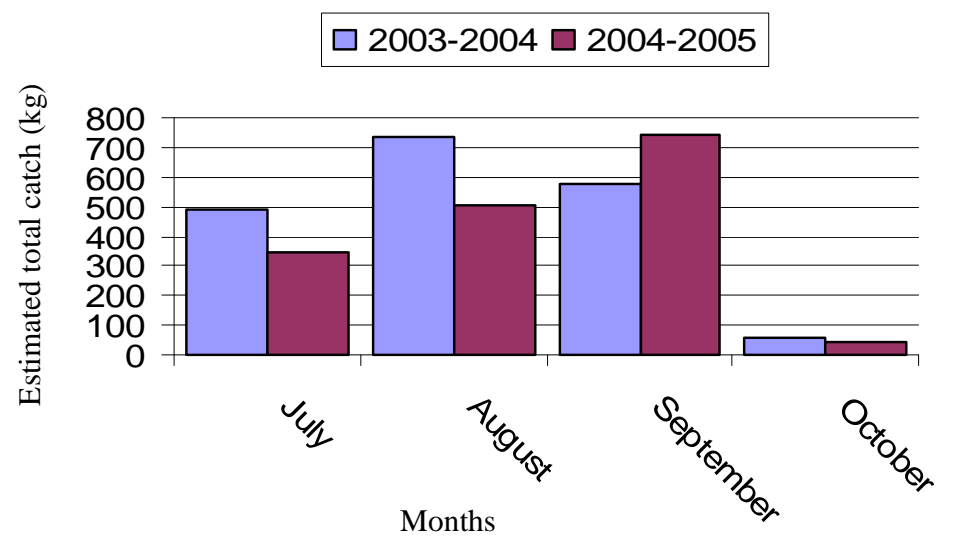

Fig.7. Monthly estimated catch of floodplain (outside) of MDIP in 2003-2004 and 2004-2005. 
(g) Meghna river (outside) : In 2003-2004, the highest monthly estimated catch was found $8311 \mathrm{~kg}$ in the month of April, followed by $5478 \mathrm{~kg}$ in May, $4631 \mathrm{~kg}$ in August, $4434 \mathrm{~kg}$ in September,4170 kg in July, $3760 \mathrm{~kg}$ in October, $3001 \mathrm{~kg}$ in February, 2956 $\mathrm{kg}$ in March and the lowest catch was $1182 \mathrm{~kg}$ in December, where, in 2004-2005, the highest catch was $3977 \mathrm{~kg}$ in August, followed by $3866 \mathrm{~kg}$ in July, $3597 \mathrm{~kg}$ in April, $3452 \mathrm{~kg}$ in September, $2621 \mathrm{~kg}$ in October, $2515 \mathrm{~kg}$ in March, $2427 \mathrm{~kg}$ in May, $2399 \mathrm{~kg}$ in June, $2124 \mathrm{~kg}$ in February and the lowest catch was $1115 \mathrm{~kg}$ in December in the same area ( Fig. 8)

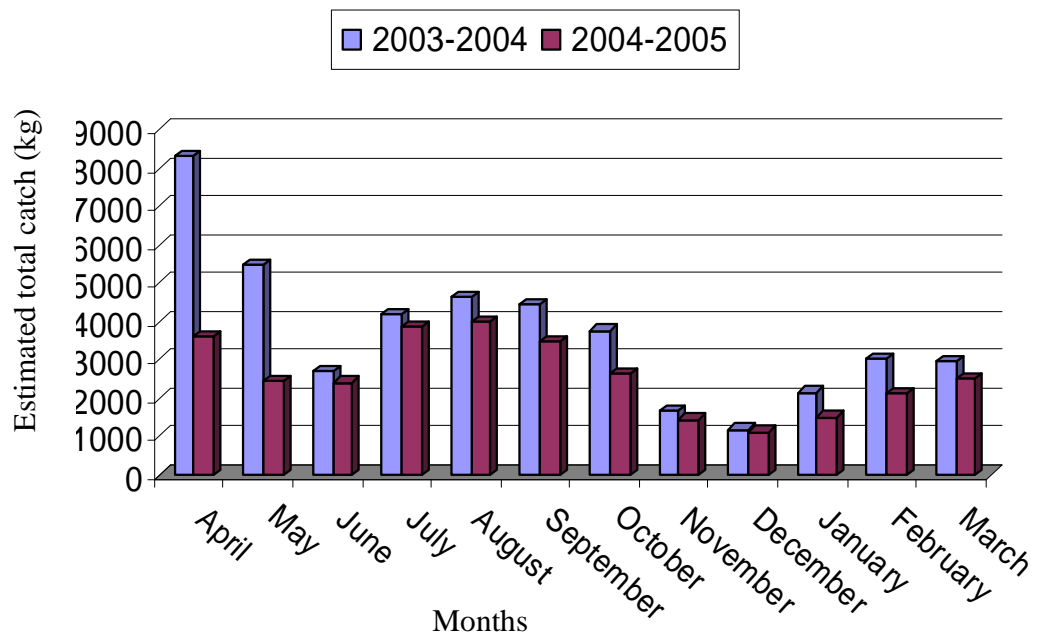

Fig. 8. Monthly estimated catch of Meghna river (outside) of MDIP in 2003-2004 and 2004- 2005.

(h) Dhonagoda river (outside): During the period of 2003-2004, it was observed that the highest monthly estimated catch was $4336 \mathrm{~kg}$ in April, followed by $3033 \mathrm{~kg}$ in February, $2964 \mathrm{~kg}$ in March, $2946 \mathrm{~kg}$ in May, $2781 \mathrm{~kg}$ in October, $2600 \mathrm{~kg}$ in December, $2342 \mathrm{~kg}$ in November and the lowest was $1200 \mathrm{~kg}$ in July respectively (Fig. 9). On the other hand, the highest catch was $2481 \mathrm{~kg}$ in October; followed by $2104 \mathrm{~kg}$ in March, $2096 \mathrm{~kg}$ in December, $1990 \mathrm{~kg}$ in February, $1950 \mathrm{~kg}$ in November and the lowest $688 \mathrm{~kg}$ was in April in 2004-2005.

The estimated catches were very high in floodplain, outside the embankment, in compare to inside inundated paddy field / floodplain. It is obvious that in all cases, the catches were always higher in the outside habitats of inland open water habitats than the same of the inside, which is the negative impact of the construction of the embankment. The natural fishes cannot enter into the inside habitats from the river due to the obstruction of the movement of fishes. This findings are similar to the study of PIRDP where it was found that low catch rates in the inside FCDI schemes (Halls 1998 and Halls et al. 1999). 
MRAG (1997) found the productivity, measured as catch per unit area, outside the Bangladesh FCDI scheme (104 and $130 \mathrm{~kg} / \mathrm{ha} / \mathrm{yr}$ in 1995 and 1996 respectively), was significantly higher than inside (51 and $81 \mathrm{~kg} / \mathrm{ha} / \mathrm{yr}$ ). Although it was far away from the present findings but when the present findings are compared between the production of inside and outside it reveals that the outside floodplain production is also significantly higher than the inside production. So, it is evident that the result of MRAG is in conformity with the present findings.

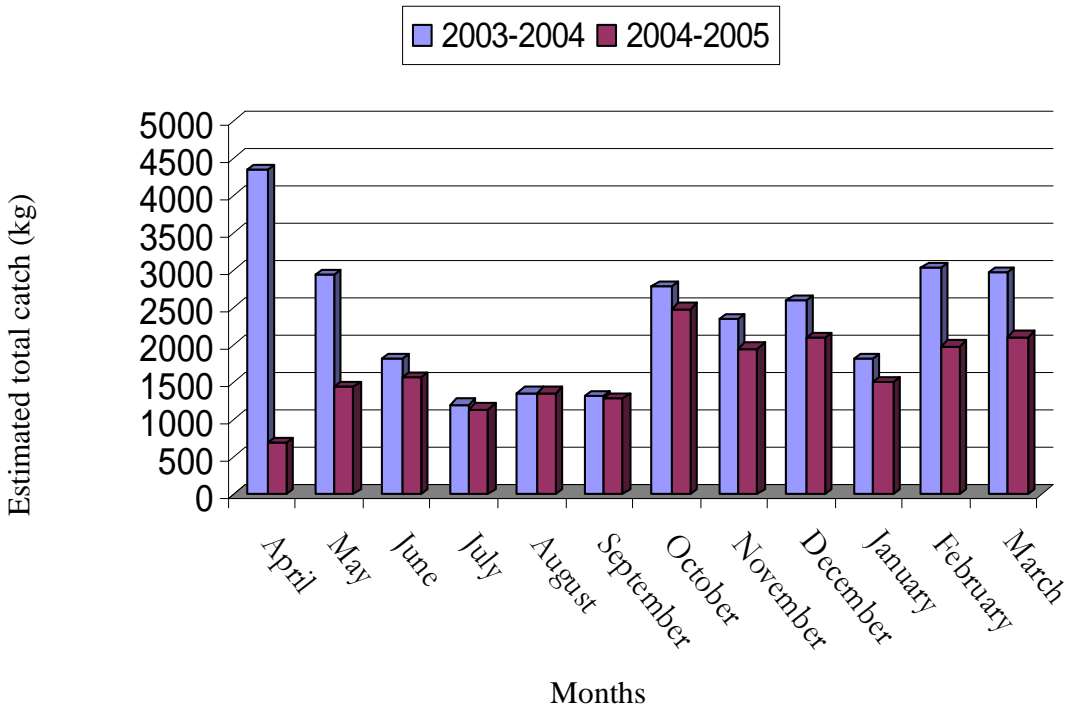

Fig. 9. Monthly estimated catch of Dhonagoaa river (outside) of MDIP in 2003-2004 and 2004-2005.

Farmers used to catch wild fish from rice fields and some estimates put these harvests at $37 \mathrm{~kg} /$ ha (MPO 1985). But in inundated paddy field, this production was found only $2.24 \mathrm{~kg} /$ ha which is lower than the statement of MPO (1985) indicating the negative impact of embankment on capture fisheries in floodplains / inundated paddy field.

Statistical analysis was done between monthly estimated catch of inundated paddy field (inside) and floodplain (outside), between khal (inside) and khal (outside), between irrigation canal (inside) and khal (outside) of equal area and it was found that statistically significant at 0.05 level $(\mathrm{p}<0.05)$ in both the years.

From two years of study, it is also evident that in Meghna and Dhonagoda river, the trends of estimated catch was diminishing in 2004-2005 than in 2003-2004. This might be due to the unavailability of fishes in the rivers adjacent to the embankment having blockage of the migration route, over fishing, implementation of the Fish Act mainly for Jatka control from the year 2004 during the months of January to May. 


\section{References}

Ali, S. M. I. and M. I. W. Zaman. 1989. Some aspects of environmental degradation of the inland open water fisheries of Bangladesh.Darjeeling University.20 pp.

BBS, 2001. Report of Household Income and Expenditure Survey 2001. Bangladesh Bureau of Statistics, Dhaka. 16 pp.

BCAS, 1991. Floodplain production monitoring--- initial study report. Bangladesh Centre for Advanced Studies, Dhaka. 99 pp.

BFRSS, 1990. Manual of Catch Assessment Survey (Revised). DOF.MOFL. Dhaka:122pp.

BFRSS, 1983-84. Fish Catch Statistics of Bangladesh. DOF.1983-84.

BFRSS, 2003-2004. Fishery Statistical Yearbook of Bangladesh. DOF. 41p.

DOF, 1995. Project proforma. Third Fisheries Project. Department of Fisheries, Government of the People's Republic of Bangladesh. 118pp.

DOF,1999. Brochure on Fish Week. Department of Fisheries, Bangladesh, Dhaka. 1999. 110pp.

DOF, 2001. Aquatic Resources Development, Management and Conservation Studies. Inception Report. Global Environmental Facility / World Bank. Goverment of the People's Republic of Bangladesh. Department of Fisheries. December 2001. 14 pp.

DOF, 2005. Brochure on Fish Fortnight. National Fish Fortnight-2005. Department of Fisheries, Ministry of Fisheries and Livestock, Dhaka, Bangladesh. 112p.

DOF, 2016. Brochure on National Fish Week 2016.Department of Fisheries, Ministry of Fisheries and Livestock, Dhaka, Bangladesh. 148pp.

FAP-12, 1992b. Project impact evaluation of Meghna- Dhonagoda Irrigation Project. FCD/I Agricultural Study FAP. Hunting Technical Services Ltd, February 1992. pp.175.

FAP- 17 (Flood Action Plan). 1995. Final Report- Main Volume. Overseas Development Administration, UK. pp. 145

FAO, 1997. Aquaculture Development. FAO Technical Guidelines for Responsible Fisheries No. 5. Rome. 58pp.

Halls, A. S. 1998. An assessment of the impact of hydraulic engineering on floodplain fisheries and species assemblages in Bangladesh. Ph.D. thesis, University of London, $526 \mathrm{pp}$.

Halls, A. S., D. D. Hoggarth, and D. Debnath. 1999. Impacts of hydraulic engineering on the dynamics and production potential of floodplain fish populations in Bangladesh. Fisheries Management and Ecology. 6(4): 261-285.

Halls, A. S., D. D. Hoggarth, and K. Debnath. 2000. Impacts of hydraulic engineering on the dynamics and production potential of floodplain fish populations in Bangladesh: implications for management. In: I.G. Cowx (eds.) Management and Ecology of River Fisheries. Oxford: Fishing News Books, Blackwell Science, pp. 201-217.

Hossain, M. 1998. A preliminary survey on the fisheries and socio-economic conditions of fishermen of the Old Bramaputra river. M. Sc. Thesis, Department of Fisheries Management . BAU, Mymensingh. 95 pp.

MPO (Master Plan Organization). 1985. Open water capture fishery resources. Ministry of Irrigation, Water Development and Flood Control.Tech. Rep. No. 16. 34 pp.

Mazid, M. A. and M. S. Hossain. 1995. Development of fisheries resources in floodplains. FRI publication no.12. Fisheries Research Institute, Mymensingh, Bangladesh (In Bangla), 16 $\mathrm{pp}$

MRAG, 1997. Fisheries Dynamics of Modified Floodplains in Southern Asia. Final Technical Report. London: MRAG, 275pp.

Nishat, A. and M. A. Bhuiyan. 1995. Strategy for Integrated Management of Land and Water in FCDI Projects with Focus on Fisheries Development. pp.139-156. In: Report of the National Workshop on Fisheries Resources Development and Management in Bangladesh. Dhaka, Bangladesh. 302 pp. 